\title{
Relationship Among Toddler Treatment, Biophysical Environment, and Toddler Morbidity in Klampar Village, Proppo District, Pamekasan Regency
}

\author{
Sri Ira Suharwati \\ STAIN Pamekasan \\ Departemnt of Social Science Education \\ Pamekasan, Indonesia \\ Coresponding email: sriirasuharwati@gmail.com \\ Siti Azizah \\ STAIN Pamekasan \\ Department of Social Science Education \\ Pamekasan, Indonesia
}

\begin{abstract}
This research aims to explain the level of toddler morbidity in Klampar village and its relationship to other factors. This research is descriptive with quantitative approach taken with survey methods. The sampling technique of respondents uses a Proportional Random Sampling technique. The data analysis technique uses Single Tabulations and Chi Square. The results of the research are: (1) the morbidity rate in Klampar village seen from a long illness and the number of sick times for the last three months that are adequate with most factors have the relationship with toddler care, (2) there is a relationship between treatment of toddlers with the toddler morbidity, (3) there is no relation between the biophysical environment with toddler morbidity in study. It is advisable for the people to further improve in taking care for toddlers, as well as maintaining good health and paying attention to the health of individuals and the environment.
\end{abstract}

Keywords - Toddler treatment, biophysical environment, morbidity

\section{INTRODUCTION}

Health level plays an important role in human life especially for survival in the future. The status of being healthy is an indicator in determining the quality of a person. The level of public health in a region or country can be seen by health statistics consisting of figures in morbidity and mortality. Figures in painmorbidity and mortality can also be used as common indicators to determine the level of socio-economic development (Kardjati et al, 1985). Socio-economic factors are indirect. It means it should follow the certain sawflies (variables between) that will cause the morbidity risks then the infants and children will be sick and if they do not get better they finally will be defective or dead (Mantra, 2003).
Morbidity is the sick degree or called also deviation from status of being healthy and prosperous usually expressed in prevalence figures or common incident common. Morbidity is an important indicator in order to have assessment and planning program to lower in morbidity and mortality in a region. Morbidity is health problems that is important especially for children under 5 years old (toddlers) because morbidity found most often for the early children. the morbidity figure is the number of diseases formulated as the number of sick children per 1000 children who can be infected by the disease (Kardjati et al, 1985).

The morbidity has the more important than mortality. The higher the level of morbidity can cause death that finally causes the decrease of human population. The death of infants and children commonly is the final consequence of the cumulative with various morbidity experience and rarely happened due to the single illness attack. The morbidity more reflects the state of health that have a good relationship with environmental factors such as poverty, lack of nutrition (undernourished), infectious diseases, housing, healthy drinking water, clean environment and health services (Kardjati et al, 1985).

Morbidity can be caused by the low education level of mothers, poverty, clean environment, and toddler environment. Toddler health status is related with some factors: those are pregnant women, giving birth mothers as well infants or children factors (Senewe, Anwar, \& Helper, 2011). According to Soetjiningsih in Shobirin (2012), the factors that could increase the disease risks among toddlers are the low education level of mothers, low socio-economic, lack of nutrition (undernourished), low weight birth, poor medical care, ineducate immunizations, and bad housing environment. 
Klampar Village is included as poor medical care of toddler until now. Based on the secondary data of Klampar POLINDES in 2013-2014 it can be seen that the toddler health level had decreased which caused an increase in morbidity. This can be seen from many toddlers who had fever, itching, diarrhea, asthma, and allergic.

Klampar village is one of the largest batik home industry in Pamekasan. The villagers make batik as their main livelihood. The number of batik craftsmen in Klampar village around 1300 people. The development of batik industry gives both the positive and negative impacts.

The positive impact of the batik development is that it can give new job opportunity so that it can reduce unemployment and increase family income. On the contrary, the negative impact that there is still no batik waste management that make the people throw it to the river. It, of course, can cause water pollution in the river since the waste from clothing industry have serious threat to the environment.Water Environmental pollution can cause various kinds of diseases that it threatens community health. Environmental pollution can be a restricting factor in the human population.

Environmental conditions such as biophysical environment is the factor causing the high morbidity in the area. Biophysical environment is housing conditions with all supporting facilities and infrastructures of hygiene and health owned by every family including the physical condition of the house, toilets, clean water source, the dump and a household waste (Shobirin, 2012). The biophysical environment affects very much on public health especially toddlers. Healthy and clean environment make people who live around it will be healthy.

The characteristic of a house is another factor that can cause the increase of the toddler morbidity. The preliminary observation can be seen that the house characteristics owned by the respondents are on the inadequate category of the healthy houses in which from the eight requirements of it, those are the condition of wall and floor that have not met by the respondents are they have to be dry and not humid and the distance of the cattle stall separated at least 10 meters from their house (Komaruddin, 1997). The results of Abidin's study (2011) described that the health environment condition causing acute diarrhea in toddlers is water source, stock of opened clean water and the existence of cattle stall around home $(<10$ meters).

Water is important component environment for the source of human life. Water resource utilization also becomes the factor of morbidity toddler cause. Various diseases such as diarrhea can spread through water (water borne diseases), and diarrhea which occurs in toddlers commonly accompanied vomiting. This proves that the environment has relationship very closely with the state of health that can become as an indication of the state of an environment.

The previous research that is in line with this research has been described by Hamzah (2009) that privy facilities of families in Kelurahan Barombong is weak, and so is water waste management most are not managed well or not having SPAL permanent because the majority of it disposed directly to the gutter or river so that it has not met the health requirement. Furthermore, another study is described by Hidayat ( 2007 ) that there is a significant relation among sanitation environment with the status of toddler nutrition with their weight according to age.

The research aims to: (1) know the level of toddler morbidity in Klampar village, Proppo District, Pamekasan, (2) know the relationship the degree of care toddler morbidity in Klampar village, Proppo District, Pamekasan, and (3) know the relationship between the biophysical environment with toddler morbidity in Klampar village, Proppo District, Pamekasan.

\section{METHOD}

This research is descriptive with quantitative approach using a survey method. In this study, the analysis unit is people in Klampar Village, Proppo districts, Pamekasan who have toddler. The sampling technique uses purposive sampling techniques. The determination of the respondents number uses Proportional Random Sampling technique in order to obtain 100 respondents.

Data collection collected by using the techniques of (1) observation and (2) the questionnaire. The data analysis technique uses descriptive analysis of single tabulations and chi-square.

\section{FINDING AND DISCUSSION}

\section{A. Level Of Toddler Morbidity}

Morbidity of toddler in this study is the number of sick toddler with the indicator level of the long illness and the number of it for three months. The following categories will be presented morbidity Klampar village in Table 1.

TABLE 1. LEVEL OF MORBIDITY TODDLER

\begin{tabular}{|l|l|c|c|}
\hline No & Morbidity & Frequency & Percentage \\
\hline 1 & High & 28 & 28 \\
2 & Medium & 58 & 58 \\
3 & Low & 14 & 14 \\
\hline & Amount & 100 & 100 \\
\hline
\end{tabular}

Based on the table above, it can be seen that toddler morbidity in Klampar village classified by medium because $58 \%$ with most of the diseases are fever, diarrhea, itching, and cough. The toddler morbidity rate in Klampar village is enough, but it will keep increasing if the people, especially mothers who have toddler do not change their lifestyles with healthy ones, which begins from their environments where they live. The morbidity rate reflects their real health because it has closely related to environmental factors such as poverty, malnutrition, infectious diseases, housing, healthy drinking 
water, environmental sanitation and health services (Kardjati et $a l, 1985)$. Based on the research, it can be seen that treatment of toddler has been linked with the toddler morbidity in Klampar village.

Toddler morbidity in Klampar village due to the frequency of the toddler having the diseases, such as: fever, diarrhea, coughing, and itching. Fever, cough, and cold could be the early symptoms of meningitis and symptoms of respiratory infection caused by the change of seasons. The intensity of contracting diarrhea in infants caused by microorganisms, as well as digestive disorders as a result of supplementary feeding at the early age, as well as malnutrition (Budiarso in Singarimbun, 1988).

Supplementary feeding for toddler under five years old in Klampar village applied since the majority of toddler are less than a month. The provision of additional improper food trigger infected of diseases such as diarrhea. For food eaten by children influential on the growth of order, anatomy and vulnerability them for disease. Therefore, the intake of food is good and healthy in childhood has an important function because childhood is an important period in the process of increasing human productivity

Increasing the number of toddlers infected by diarrhea in the klampar village also can be caused by environmental conditions such as water pollution. Water pollution capable of transmitting various diseases to the toddlers such as sickness types, dysentery, and diarrhea. So as to prevent and reduce morbidity should be the availability of sufficient clean water and also their need consult about the importance of maintaining healthy environment, personal and toddler treatment the way of supplementary food in infants in accordance with their ages and needs.

\section{B. Relation Between Treatment Of Toddlers With The Morbidity Toddler}

In this research, the treatment of toddler measured began from toddler in the womb until they were born. The toddler data treatment in the womb namely the intensity of pregnancy examination, pregnancy examination place, helper during childbirth, while the data after birth is the intensity of toddler health examination, toddlers' health examination place, routine advisability coming to Posyandu, and the status of KMS ownership. The following can be known the relationship between toddler treatment and toddler morbidity in Table 2.
TABLE 2.RELATION BETWEEN TREATMENT OF TODDLERS WITH THE MORBIDITY

\begin{tabular}{|l|r|c|c|c|c|c|}
\hline \multirow{3}{*}{$\begin{array}{c}\text { Treatment of } \\
\text { toddlers }\end{array}$} & \multicolumn{6}{|c|}{ Morbidity } \\
\cline { 2 - 7 } & \multicolumn{2}{|c|}{ High } & \multicolumn{2}{c|}{ Medium } & \multicolumn{2}{c|}{ Low } \\
\cline { 2 - 7 } & $\boldsymbol{F}$ & $\boldsymbol{\%}$ & $\boldsymbol{F}$ & $\boldsymbol{\%}$ & $\boldsymbol{F}$ & $\%$ \\
\hline Low & 7 & $25 \%$ & 11 & $19 \%$ & 4 & $29 \%$ \\
Medium & 11 & $39 \%$ & 31 & $53 \%$ & 8 & $57 \%$ \\
High & 10 & $36 \%$ & 16 & $28 \%$ & 2 & $14 \%$ \\
\hline \multicolumn{1}{|c|}{ Amount } & 28 & 100 & 58 & 100 & 14 & 100 \\
\hline
\end{tabular}

Based on the above table it can be seen that the treatment of toddler in Klampar village is medium so they have the morbidity rate is also medium, for $53 \%$ (31 respondents). Based on the results of the chi-square obtained of Chi-Square test > Chi-Square table (8.743> 5.991), then Ho is rejected, which means there is a connection between toddler treatment with toddler morbidity.

In order to preserve and maintain the health of toddlers, there are several things to note that is how the actions of the mother in caring for her baby health beginning in the womb until birth. Treatment here begins from infant, by controlling her toddler growth and development, a healthy and proper diet, and giving the basic vaccines (Entjang, 1981). In this research, there are many mothers who have toddler not paying attention on how to treat their toddler. The toddler treatment needs high attention from the mother, because the lack of attention to the toddler health, it will cause morbidity in toddlers. If it happens continually, it will cause the number of toddler mortality in Klampar village increasing.

The research results show that the low level of toddler health treatment in Klampar village due to lack of mother's attention to the health of their babies. It is seen from the completeness of immunization given by their mothers when the children under one year. Immunization is a way to increase immunity someone actively for a cure. Immunization aims to prevent disease and reduce the mortality rate of infants and children due to disease outbreaks. Immunization is also effective for preventing six infectious diseases such as diphtheria, tetanus, whooping cough, polio, tuberculosis and measles on child.

In Klampar village, most of the mothers do not give their children immunization after they are born. In addition, completeness of immunization given by the mother is still considered incomplete, it is because respondents are not routine joining the activities in posyandu in Klampar village. In fact, based on the previous study shows that infectious diseases such as diftria, whooping cough, polio, and tetanus neonatorium can be prevented by immunization (Kardjati et al, 1985). Although the mother's act when their children are sick checked them to the midwife, but early prevention from the disease has been no favorable response from the mothers. In addition, there are still a high using quack service by the mothers in Klampar village during the process childbirth process also affects the toddler health after birth. 
The relevant research is Shobirin research (2012) conducted in the Puncu district of Kediri which concluded that the treatment toddler is the most variable for the high toddler morbidity. Another study is Nurianti's research (2010) conducted in the Scavenger village of Sidomulyo, Tanjungrejo Sub-District, Sukun District, Malang which concluded that there is a correlation between the treatment of toddler with morbidity in which there were many respondents not treated their babies properly so high morbidity in the study area was caused by the carelessness of the mother in the care of toddler.

The low care toddlers due to the low education of their mothers. The low and high of mothers' education is closely related to the level of understanding of health care, hygiene, the importance of prenatal care, and postpartum, as well as awareness of the health of children and their families (Kardjati et al, 1985 ). Senewe, Anwar, and Helper (2011) research findings, the biggest risk factor related to morbidity status children under five was low education level for head of household (OR 1,1\%). Another research is Budijanto and Singgih (2016) Showed that health behaviors affect the infant morbidity. Associated with knowledge and attitudes towards environmental health is good, but their actions are less.

\section{Relation Between The Biophysical Environment With Morbidity Toddler}

Biophysical environment which is used as an indicator of a healthy environment in the research include: clean water is used, sanitary facilities, landfills, waste dumps households, and the characteristics of the house which includes the status of home ownership, type of floor, wall type, and whether there is or not clean air into the house. Here can be seen with the biophysical environment relation with morbidity toddler in Table 3.

TABLE 3. RELATION BETWEEN BIOPHYSICAL ENVIRONMENT WITH MORBIDITY TODDLER

\begin{tabular}{lrrrrrr}
\hline \multirow{2}{*}{$\begin{array}{c}\text { Biophysical } \\
\text { Environment }\end{array}$} & \multicolumn{6}{c}{ Morbidity } \\
\cline { 2 - 7 } & \multicolumn{2}{c}{$\boldsymbol{H i g h}$} & \multicolumn{2}{c}{ Medium } & \multicolumn{2}{c}{ Low } \\
\cline { 2 - 7 } & $\boldsymbol{F}$ & $\boldsymbol{\%}$ & $\boldsymbol{F}$ & $\boldsymbol{\%}$ & $\boldsymbol{F}$ & $\boldsymbol{\%}$ \\
\hline Low & 3 & $10 \%$ & 23 & $40 \%$ & 2 & $14 \%$ \\
Medium & 20 & $69 \%$ & 22 & $39 \%$ & 10 & $72 \%$ \\
High & 6 & $21 \%$ & 12 & $21 \%$ & 2 & $14 \%$ \\
\hline \multicolumn{1}{c}{ Amount } & 29 & 100 & 57 & 100 & 14 & 100 \\
\hline
\end{tabular}

Based on the above table shows that the lower the biophysical environment have the high morbidity rate of $10 \%$ (3 respondents), respondents with the condition have the biophysical environment is being morbidity rate was also as much as $39 \%$ (22 respondents). While respondents who have biophysical environment with high category have the low morbidity rate as much as $14 \%$ ( 2 respondents). Based on test results obtained Chi Square value for Chi-Square count $<$ ChiSquare table $(35,907<41,337)$, then Ho is accepted, which means there is no relationship between the biophysical environment with toddler morbidity. According Entjang (1981) that the places where hygiene and environmental sanitation repaired, the mortality, morbidity decline and the epidemic reduced by itself. Biophysical environment greatly affects the public health especially toddlers. A clean and healthy environment makes people who live in the environment becomes healthy. In connection with infant health, living conditions greatly affect infant health. This is due to very vulnerable infants infected with diseases that exist in the environment.

Based on the results of this research is that the biophysical environment house does not have a relationship with toddler morbidity in Klampar village. Biophysics environment that is in Klampar village classified in the medium category. Although there were some respondents who own a home that does not qualify as a healthy home such as many of the respondents who have the cattle shed not far from their house. In using clean water, Klampar villagers are also classified as moderate because many of them choose to use the well water for eating and drinking. Although until now there are still some people who use the river water to meet their daily needs. However, because the use of river water not every time or it is just occasionally so it will be a little chance to infect the disease.

The different research with this research is Abidin's study (2011) conducted in South Lampung regency concluded that the environmental health conditions that are risk factors for the occurrence of acute diarrhea in children under five is a surface water source, water storage areas clean open and the presence of cattle sheds around the house $(<10$ meters). Other research having a difference is Nurianti research (2010) in the Scavenger village of Sidomulyo, Tanjungrejo Sub-district, Sukun District in Malang which concludes that sanitation having a significant effect on toddler morbidity. This happened because some respondents have not realized the importance of the residence sanitation on health.

\section{CONCLUSIONS AND SUGGESTION}

The conclusion in this study is as follows:

- The level of morbidity in Klampar village can be seen from a long illness and the number of sick times for the last three months is medium with the most related factor is toddler treatment. The types of disease that is often suffered by toddler are fever, diarrhea, and itchy,

- Treatment of toddler in Klampar village is in medium category. Based on test by Chi Square shows that there is relationship between toddler treatment with morbidity, and

- Biophysical environment in Klampar village by Chi-Square test showed that there was no relationship between the biophysical environment with toddler morbidity.

It is advisable for the people to do better improvement since the pregnancy until the baby is born. A good toddler treatment is an indicator that a person's health status is also good in order to be able to improve the quality of the person. While for the government, it is advisable to conduct counseling on the importance of maintaining the health, both the body and the environment. 


\section{REFERENCES}

[1] Abidin, Z, 2011, "Faktor Risiko Kesehatan Lingkungan Yang Berpengaruh Terhadap Kejadian Diare Studi Diare Akut Pada Balita di Kabupaten Lampung Selatan", Tesis, Diponegoro University, Semarang.

[2] Budijanto \& Singgih, 2016, "Environmental Health Behavior and Morbidity of Children in Community Settlement Brantas Riverbanks Malang", Journal of Environment and Earth Science, vol 6, State University of Malang.

[3] Entjang \& Indang, 1981, "Ilmu Kesehatan Masyarakat", Alumni, Bandung.

[4] Hamzah \& Pratiwi N, 2009, "Fasilitas Jamban Keluarga Dan Pengelolaan Air Limbah Di Kelurahan Barombong Kecamatan Tamalate Tahun 2009”. Indonesian Moslem University, Makassar.

[5] Hidayat, TS, et al, "Hubungan Sanitasi Lingkungan, Morbiditas Dan Status Gizi Balita Di Indonesia”, 2007, Ejurnal Litbang Depkes, vol 34(2), pp 04-113.

[6] Kardjati, Alisjahbana, \& J.A. Kusin. 1985, “Aspek Kesehatan Dan Gizi Anak Balita", Yayasan Obor Indonesia, Jakarta.

[7] Senewe, Anwar, \& Helper, 2011, "The Effect of Environmentfor Children Under-Five Morbidity Status in Disadvanteged Region 2008", Journal of Ecological Health, vol 10, pp 54-64.

[8] Singarimbun, M, 1998, "Kelangsungan Hidup Anak", Gajah Mada, Yogyakarta.

[9] Shobirin, W, 2012, "Pengaruh Kondisi Ekonomi, Tingkat Pendidikan, Demografi, Perawatan Balita, dan Lingkungan Biofisik Terhadap Morbiditas Balita Di Kecamatan Puncu Kabupaten Kediri”, State University of Malang, Malang. 